\title{
PROFIL MISKONSEPSI SISWA KELAS X SMKN 4 MATARAM PADA MATERI POKOK SUHU, KALOR, DAN PERPINDAHAN KALOR
}

\author{
P. Ayu Suci Lestari ${ }^{1}$, Satutik Rahayu ${ }^{2}$, Hikmawati ${ }^{2}$ \\ 1) Program Studi Pendidika Fisika \\ 2) Program Studi Pendidika Fisika FKIP \\ Universitas Mataram \\ Mataram, Indonesia \\ Email: p.ayusucilestari@gmail.com
}

\begin{abstract}
This research aimed to describe the students misconception profile for grade X SMKN 4 Mataram on the subject matter of Temperature, Heat, and Heat Transfer. This research is descriptive with case study design. The population in this research were all students of grade X SMK 4 Mataram which amounts to 424 people. The sampling technique used was purposive sampling, so that the sample in this research were all students of grade $\mathrm{X}$ SMK 4 Mataram except for class X of Office Administration 1 (X APK 1) and X of Office Administration 2 (X APK 2) which amounts to 333 people, because only both of this grade that do not get science subjects. Data were obtained from the test instrument identification shaped misconceptions reasoning multiple choice with an open reasoning and the analyzed using descriptive statistics which have previously been validated by one person subject teacher Science grade X and two person physical education lecturer. Based on this research, it was found that the students of grade X SMK 4 Mataram academic year 2014/2015 have misconceptions identified by the average percentage of misconceptions on the concept of temperatures by $11.53 \%$, on the concept of heat by $16.44 \%$, on the concept of expansion by $8.61 \%$, and on the concept of heat transfer by $15.22 \%$, so it can be concluded that the misconceptions experienced by the students of grade X SMK 4 Mataram in Akademic Year 2014/2015.
\end{abstract}

Keywords: Concept of Heat, and Concept of Heat Transfer, Concept of Temperature, Misconceptions Profile.

\section{PENDAhUluan}

Kualitas pendidikan Sains saat ini belum menunjukkan relevansi yang tinggi dengan kebutuhan masyarakat. Selain relevansi dengan kebutuhan, permasalahan penting dalam pembelajaran Sains adalah rendahnya kualitas pembelajaran pada berbagai jenjang pendidikan [1]. Berdasarkan UU SISDIKNAS No. 20 Tahun 2003 tentang Sistem Pendidikan Nasional menyatakan bahwa, tujuan pendidikan nasional adalah untuk mengembangkan potensi peserta didik agar menjadi manusia beriman dan bertakwa kepada Tuhan Yang Maha Esa, berahlak mulia, sehat, berilmu, cakap, kreatif, mandiri, dan menjadi warga Negara yang demokratis, serta bertanggung jawab. Tujuan pendidikan nasional ini mencakup tiga kelompok kemampuan, yaitu kemampuan berpikir, kemampuan berbuat, dan prilaku atau perbuatan. Tujuan ini pula yang menjadi landasan dalam merancang proses pembelajaran Sains (IPA) [2].
Sains (IPA) ialah suatu cara mencari tahu tentang alam secara sistematis untuk menguasai pengetahuan, fakta-fakta, konsep-konsep, prinsip-prinsip, proses penemuan dan memiliki sikap ilmiah [3]. Salah satu bagian dari sains (IPA) adalah fisika, yang pada hakikatnya merupakan kumpulan pengetahuan, cara penyelidikan, dan cara berpikir yang dipandang sebagai suatu produk, proses, dan sikap, sehingga dalam pembelajarannya harus mempertimbangkan strategi atau metode pembelajaran yang efektif dan efisien [3].

Oleh karena mata pelajaran IPA (Fisika) ini terdiri atas komponen konsep, dimana siswa ditargetkan terampil dalam menerapkan konsep-konsep IPA (Fisika), maka untuk mencapai sasaran ini siswa dituntut untuk memahami konsep-konsep IPA (Fisika) sebagai hasil dari pengetahuan yang diperolehnya, karena sesungguhnya belajar IPA (Fisika) mencakup dua dimensi yaitu proses dan hasil, sehingga siswa tidak hanya sekedar mengingat saja apa yang telah dipelajari tetapi juga harus memiliki konsepsi yang benar [4]. Setiap konsep tidak berdiri sendiri, 146 
melainkan selalu berhubungan dengan konsep-konsep yang lain. Maka setiap konsep dapat dihubungkan dengan banyak konsep lain dan hanya mempunyai arti dalam hubungan dengan konsep-konsep lain. Semua konsep secara bersama-sama membentuk semacam jaringan pengetahuan di dalam pikiran manusia. Perlu diketahui, Siswa sering membangun teori mereka sendiri tentang bagaimana alam bekerja, sebelum pendidikan sains formal [5]. Selain itu, siswa juga telah memiliki konsep-konsep yang dipahaminya berdasarkan pengalaman kesehariannya. Konsepkonsep yang didapatkan dari keseharian ini bisa bersumber dari orang tua, teman, dan lingkungannya yang bisa jadi tidak sesuai dengan konsep yang diyakini oleh para ahli [6]. Konsep-konsep yang dikembangkan oleh siswa ini juga sering tidak cocok dengan konsep-konsep ilmiah [7].

Berdasarkan hasil wawancara yang telah dilakukan dengan salah seorang guru mata pelajaran IPA di SMKN 4 Mataram, diketahui bahwa mata pelajaran IPA di sekolah ini sebelumnya menggunakan Kurikulum KTSP yang hanya mencakup mengenai pelajaran IPA secara umum. Akan tetapi sejak penerapan Kurikulum 2013 pada bulan Juli tahun 2014, cakupan materi dalam pembelajaran IPA sudah lebih mengarah ke IPA Aplikasi atau IPA Terapan. Oleh karena itu, dibutuhkan pemahaman konsep dalam pembelajaran IPA Aplikasi/Terapan ini. Selain itu, didapatkan pula informasi mengenai belum tersedianya buku literatur untuk mata pelajaran IPA pada jenjang SMK. Buku literatur yang dimaksud adalah buku literatur yang diterbitkan oleh Depdiknas yaitu buku guru dan buku siswa.

Ketidaktersediaan buku literatur untuk mata pelajaran IPA ini, dirasa cukup menjadi kendala dalam proses pembelajaran. Guru juga memberi pernyataan bahwa untuk materi-materi pada semester 1 (Ganjil) Tahun Pelajaran 2014/2015, tidak sedikit siswa yang mengalami miskonsepsi. Bahkan dari sejumlah siswa di dalam kelas, tak banyak siswa memiliki konsep awal yang benar.

Hal-hal tersebut di atas tentu saja dapat menghambat pemahaman siswa akan konsep, bahkan berpeluang menimbulkan kesalahan dalam memahami konsep. Kesalahan dalam memahami konsep ini biasanya disebut dengan istilah miskonsepsi. Miskonsepsi ini terdapat dalam semua bidang sains, seperti fisika, biologi, kimia, dan astronomi. Miskonsepsi dalam bidang fisika meliputi banyak subbidang seperti mekanika, termodinamika, optika, bunyi dan gelombang, listrik dan magnet, serta fisika modern [8]. Adapun salah satu materi pokok yang ada pada subbidang termodinamika untuk jenjang SMK kelas $\mathrm{X}$ adalah materi pokok Suhu, Kalor, dan Perpindahan Kalor.

Berdasarkan pemaparan di atas, peneliti memilih konsep Suhu, Kalor, dan Perpindahan Kalor yang ada di semester II (Genap) Tahun Pelajaran 2014/2015 untuk diteliti karena merupakan materi yang paling sering berkaitan dengan kehidupan sehari-hari siswa, sehingga lebih memudahkan peneliti dalam mengidentifikasi miskonsepsi siswa kelas X SMKN 4 Mataram.

Sesuai dengan permasalahan yang telah dirumuskan di atas, maka tujuan penelitian ini adalah untuk mendeskripsikan profil miskonsepsi siswa kelas X SMKN 4 Mataram pada materi pokok Suhu, Kalor, dan Perpindahan Kalor. Hasil penelitian ini diharapkan dapat memberikan manfaat berupa sumbangan positif terhadap pengembangan pembelajaran IPA khususnya fisika, serta dapat bermanfaat bagi kepala sekolah, guru, mahasiswa, serta peneliti yang ingin mengambil kajian yang sama.

\section{Tinjauan Pustaka}

\section{A. Belajar Konsep}

Proses pendidikan di sekolah diisi oleh kegiatan belajar yang merupakan kegiatan yang paling pokok. Ini berarti berhasil atau tidaknya pencapaian tujuan pendidikan banyak bergantung pada bagaimana proses belajar yang dialami oleh siswa selaku peserta didik.

Para siswa sering hanya menghafalkan definisi konsep tanpa memperhatikan hubungan antara konsep yang satu dengan yang lain. Dengan demikian konsep baru yang dipelajari tidak dapat dipahami atau dicerna dengan mudah oleh siswa, akan tetapi konsep tersebut berdiri sendiri dan tidak memiliki hubungan dengan konsep lainnya. Konsep baru tersebut tidak dapat digunakan oleh siswa dan tidak memiliki arti [6].

Dasar dari belajar konsep adalah sama halnya dengan bentuk belajar yang lain berupa asosiasi stimulus dan respon, dimana biasanya konsep awal itu kurang sempurna, maka perlu dikembangkan atau dibenahi dalam pelajaran formal [8]. Selain itu, [9] mengemukakan adanya dua pendekatan yang digunakan dalam belajar konsep yaitu pendekatan 
perilaku dan pendekatan kognitif. Hal ini menunjukkan bahwa belajar konsep bukanlah menghafal konsep tetapi merupakan proses menghubungkan konsep awal dengan konsep baru sehingga akan diperoleh konsep akhir yang diinginkan.

\section{B. Miskonsepsi}

Miskonsepsi adalah konsep yang dimiliki oleh peserta didik dan diyakini kebenarannya tetapi tidak sesuai dengan kebenaran universal [8]. Ciri-cirinya menurut [9] adalah sebagai berikut:

a. Sangat tahan terhadap perubahan, sehingga sulit diubah.

b. Menjadi pengganggu terhadap pemahaman konsep IPA (fisika) lanjutan walaupun untuk soal-soal sederhana.

c. Regresional yaitu siswa yang pernah mengalami miskonsepsi IPA (fisika), beberapa lama kemudian akan mengalami kesalahan kembali.

d. Tidak dapat dihilangkan melalui ceramah yang baik.

e. Setiap individu baik siswa, mahasiswa, guru maupun dosen, dapat mengalami miskonsepsi IPA (fisika).

Siswa yang pandai dan yang kurang pandai, keduaduanya dapat mengalami miskonsepsi IPA (fisika).

Penyebab dari miskonsepsi IPA (fisika) secara garis besar menurut para ahli yang terangkum dalam [8] adalah siswa, guru/pengajar, buku teks, konteks, dan cara mengajar. Adapun cara mendeteksi miskonsepsi yang sering digunakan oleh para peneliti dan guru dijabarkan oleh [8] yaitu peta konsep (concept maps), tes multiple choice dengan reasoning terbuka, tes esai tertulis, wawancara diagnosis, diskusi dalam kelas, praktikum dan tanya jawab.

Terdapat banyak cara untuk membantu siswa mengatasi miskonsepsi dalam bidang IPA (fisika). Banyak penelitian telah dilakukan oleh para ahli pendidikan fisika, biologi, kimia, dan astronomi yang mengungkapkan bermacam-macam kiat yang dibuat untuk membantu siswa memecahkan persoalan miskonsepsi. Secara garis besar langkah yang digunakan untuk membantu mereduksi miskonsepsi menurut [8] adalah mencari atau mengungkap miskonsepsi yang dilakukan siswa, mencoba menemukan penyebab miskonsepsi tersebut, dan mencari perlakuan yang sesuai untuk mengatasi.

\section{Metode PENELITIAN}

Penelitian ini merupakan penelitian deskriptif yang merupakan penelitian untuk memberikan uraian mengenai gejala, fenomena, atau fakta yang diteliti dengan mendeskripsikan tentang nilai variabel tanpa bermaksud membandingkan [11]. Tujuan utama dari penelitian deskriptif adalah untuk membuat deskripsi atau gambaran secara sistematis dan akurat mengenai fakta-fakta dari fenomena yang diselidiki [4]. Penelitian ini dilaksanakan mulai bulan September 2014 sampai bulan Mei 2015 bertempat di SMKN 4 Mataram. Desain penelitian yang digunakan pada penelitian miskonsepsi ini adalah desain penelitian studi kasus yang merupakan kajian yang rinci tentang satu latar, subjek tunggal, atau suatu peristiwa tertentu. Kasus bisa berupa individu, keluarga, atau komunitas masyarakat tertentu [11].

Adapun populasi dalam penelitian ini adalah seluruh siswa kelas X SMKN 4 Mataram, sedangkan sampelnya adalah seluruh siswa kelas X kecuali siswa kelas X Administrasi Perkantoran 1 (X APK 1) dan X Administrasi Perkantoran 2 (X APK 2) yang diambil dengan mengunakan teknik purposive sampling karena tidak semua kelas X di SMKN 4 Mataram yang mendapatkan mata pelajaran IPA, sehingga seluruh sampel ini berjumlah 333 siswa.

Instrumen yang digunakan untuk pengumpulan data adalah tes identifikasi miskonsepsi yang berupa tes multiple choice dengan reasoning terbuka sebanyak 25 butir yang berupa soal-soal konsep Suhu, Kalor, dan Perpindahan Kalor yang telah dipelajari siswa, dimana instrumen ini telah terlebih dahulu melalui proses uji validitas isi. Untuk instrumen yang berbentuk tes, pengujian validitas isi dapat dilakukan dengan membandingkan antara isi instrumen dengan materi pelajaran yang telah diajarkan [12]. Pengumpulan data dilakukan untuk memilih dan memberi skor pada data-data jawaban siswa dalam mengerjakan soal berdasarkan kategori tidak paham konsep, miskonsepsi, dan paham konsep [11].

Data yang didapatkan dari hasil tes identifikasi selanjutnya dianalisis menggunakan statistik deskriptif serta dilengkapi dengan deskripsi profil miskonsepsi siswa yang diperoleh dengan menghitung persentase jawaban siswa pada tiap butir soal, membuat tabel 
frekuensi dan persentase tingkat pemahaman siswa, membuat diagram tingkat pemahaman siswa berdasarkan persentase hasil jawaban tes identifikasi miskonsepsi, serta membuat tabel persentase rata-rata siswa yang mengalami miskonsepsi pada tiap tipe soal miskonsepsi.

\section{Hasil Dan PEMbahasan}

Langkah awal analisis deskriptif yang dilakukan peneliti adalah memeriksa dan mengelompokkan jawaban siswa pada setiap butir soal ke dalam tiga kategori yaitu memahami konsep, miskonsepsi, dan tidak memahami konsep. Adapun data tingkat pemahaman konsep, miskonsepsi, dan ketidak pahaman konsep siswa berdasarkan hasil analisis data yang telah dilakukan adalah sebagai berikut:

Tabel 1. Data Tingkat Pemahaman Siswa

\begin{tabular}{llrrc}
\hline No & \multicolumn{1}{c}{ Tipe Konsep } & $\begin{array}{c}\text { Tidak Paham } \\
\text { Konsep (TP) }\end{array}$ & $\begin{array}{c}\text { Miskonsepsi } \\
(\mathbf{M})\end{array}$ & $\begin{array}{c}\text { Paham } \\
\text { Konsep } \\
(\mathbf{P})\end{array}$ \\
\hline 1 & Konsep Suhu & $30.57 \%$ & $11.53 \%$ & $57.46 \%$ \\
2 & Konsep Kalor & $41.74 \%$ & $16.44 \%$ & $41.70 \%$ \\
3 & Konsep Pemuaian & $46.85 \%$ & $8.61 \%$ & $44.53 \%$ \\
4 & Konsep Perpindahan Kalor & $37.29 \%$ & $15.22 \%$ & $47.35 \%$ \\
\hline
\end{tabular}

Tabel di atas menunjukkan bahwa dari 333 siswa yang diteliti, terlihat bahwa persentase tingkat pemahaman atas, dapat dibuat diagram seperti pada gambar berikut konsep siswa cukup beragam. Berdasarkan Tabel 1 di

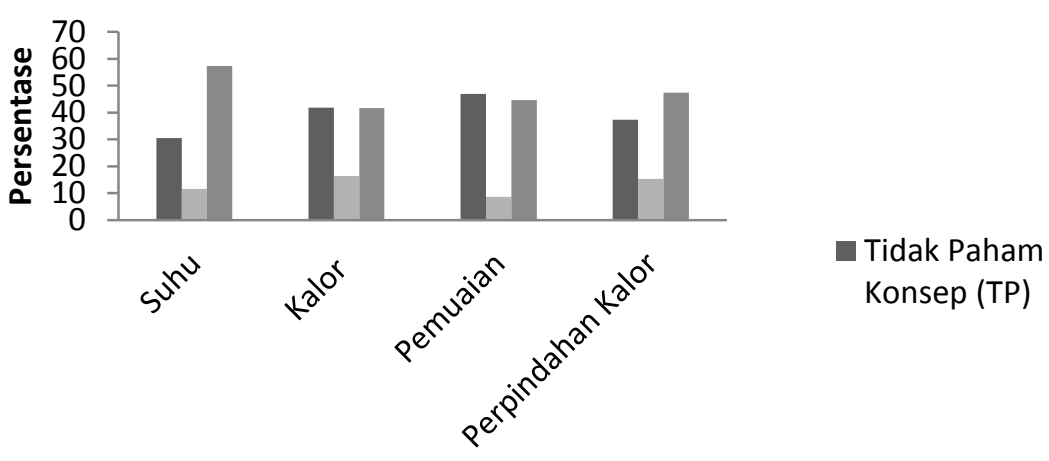

Konsep

Gambar 1. Diagram Data Tingkat Pemahaman Siswa

Gambar di atas menunjukkan bahwa siswa mengalami miskonsepsi pada semua tipe konsep. Miskonsepsi dengan persentase tertinggi terjadi pada konsep kalor yakni sebesar 16.44\%. Sebaliknya, miskonsepsi dengan persentase terendah terjadi pada konsep pemuaian yakni sebesar $8.61 \%$.
Agar data di atas lebih terperinci, maka data-data tersebut dibuat dalam bentuk rekapitulasi sehingga dapat disajikan secara lengkap frekuensi dan persentase tingkat pemahaman siswa pada masingmasing kategori untuk setiap butir soal sebagai berikut: 
Tabel 2. Frekuensi dan Persentase Tingkat Pemahaman Siswa

\begin{tabular}{|c|c|c|c|c|c|c|}
\hline \multirow{2}{*}{$\begin{array}{l}\text { No. } \\
\text { Soal }\end{array}$} & \multicolumn{2}{|c|}{$\begin{array}{c}\text { Tidak Paham Konsep } \\
\text { (TP) }\end{array}$} & \multicolumn{2}{|c|}{ Miskonsepsi (M) } & \multicolumn{2}{|c|}{ Paham Konsep (P) } \\
\hline & Frekuensi & $\%$ & Frekuensi & $\%$ & Frekuensi & $\%$ \\
\hline \multicolumn{7}{|c|}{ Konsep Suhu } \\
\hline 1. & 11 & 3.30 & 35 & 10.51 & 287 & 86.19 \\
\hline 2. & 79 & 23.72 & 96 & 28.83 & 158 & 47.45 \\
\hline 3. & 66 & 19.82 & 27 & 8.11 & 240 & 72.07 \\
\hline 4. & 210 & 63.06 & 12 & 3.61 & 111 & 33.33 \\
\hline 5. & 141 & 42.34 & 22 & 6.61 & 159 & 47.75 \\
\hline \multicolumn{7}{|c|}{ Konsep Kalor } \\
\hline 6. & 25 & 7.51 & 55 & 16.51 & 253 & 75.98 \\
\hline 7. & 195 & 58.56 & 19 & 5.71 & 116 & 34.83 \\
\hline 8. & 226 & 67.87 & 27 & 8.11 & 80 & 24.02 \\
\hline 9. & 161 & 48.34 & 22 & 6.61 & 150 & 45.05 \\
\hline 10. & 290 & 87.09 & 8 & 2.40 & 35 & 10.51 \\
\hline 11. & 127 & 38.14 & 28 & 8.41 & 178 & 53.45 \\
\hline 12. & 66 & 19.82 & 96 & 28.83 & 171 & 51.35 \\
\hline 13. & 22 & 6.61 & 183 & 54.95 & 128 & 38.44 \\
\hline \multicolumn{7}{|c|}{ Konsep Pemuaian } \\
\hline 14. & 143 & 42.94 & 16 & 4.81 & 174 & 52.25 \\
\hline 15. & 170 & 51.05 & 40 & 12.01 & 123 & 36.94 \\
\hline 16. & 137 & 41.14 & 45 & 13.51 & 151 & 45.35 \\
\hline 17. & 222 & 66.67 & 31 & 9.31 & 80 & 24.02 \\
\hline 18. & 79 & 23.72 & 28 & 8.41 & 226 & 67.87 \\
\hline 19. & 186 & 55.86 & 12 & 3.60 & 136 & 40.84 \\
\hline \multicolumn{7}{|c|}{ Konsep Perpindahan Kalor } \\
\hline 20. & 112 & 33.63 & 39 & 11.72 & 179 & 53.75 \\
\hline 21. & 138 & 41.44 & 70 & 21.02 & 125 & 37.54 \\
\hline 22. & 73 & 21.92 & 76 & 22.82 & 184 & 55.26 \\
\hline 23. & 169 & 50.75 & 49 & 14.72 & 115 & 34.53 \\
\hline 24. & 186 & 55.86 & 56 & 16.81 & 91 & 27.33 \\
\hline 25. & 67 & 20.12 & 14 & 4.20 & 252 & 75.68 \\
\hline
\end{tabular}

Berdasarkan tabel di atas, maka dapat dikemukakan bahwa siswa mengalami miskonsepsi pada semua butir soal yang di ujikan. Selain itu, berdasarkan data jawaban 333 siswa yang didapatkan, diketahui bahwa tidak ada satupun siswa yang menjawab benar pada semua soal yang di ujikan. Berdasarkan Tabel 2 di atas, dapat dibuat diagram seperti pada gambar berikut ini: 


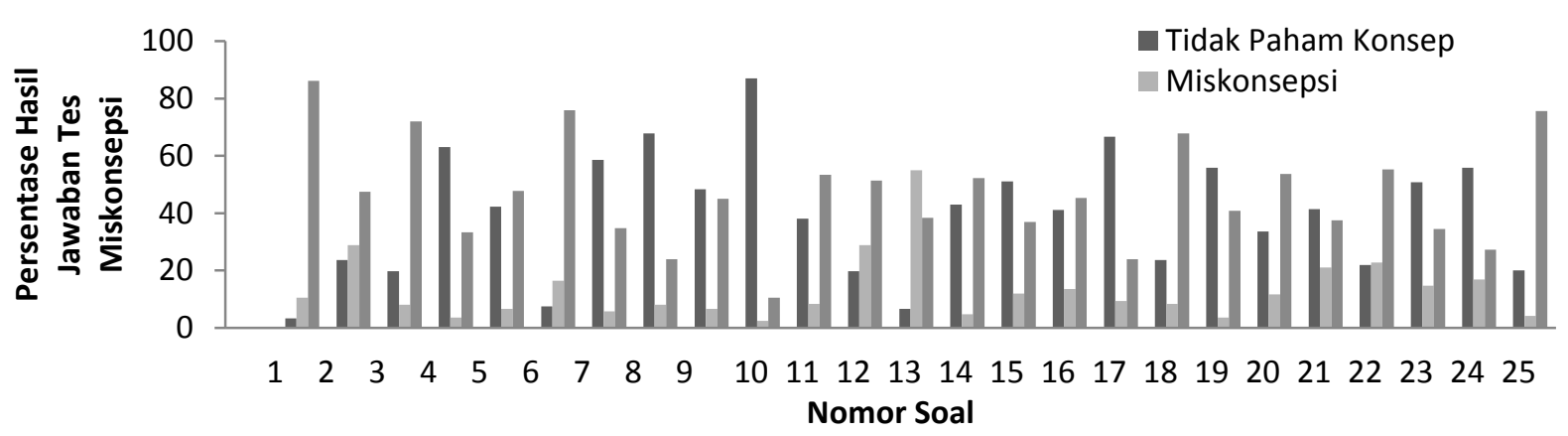

Gambar 2. Diagram Batang Hasil Tes Identifikasi Miskonsepsi

Gambar di atas menunjukkan bahwa siswa memiliki tingkat miskonsepsi yang berbeda-beda pada setiap soal. Soal yang memiliki persentase jawaban miskonsepsi paling tinggi adalah soal nomor 13 dengan persentase $54.95 \%$, sedangkan soal yang memiliki persentase jawaban miskonsepsi paling rendah adalah nomor 10 dengan persentase $2.40 \%$.
Berdasarkan analisis data lanjut terhadap lembar jawaban siswa, maka diperoleh persentase rata-rata siswa yang mengalami miskonsepsi pada setiap tipe soal miskonsepsi yang ditunjukkan oleh tabel di bawah ini:

Tabel 3. Persentase Rata-Rata Siswa Yang Mengalami Miskonsepsi Pada Tiap Tipe Soal Miskonsepsi

\begin{tabular}{clc}
\hline No. & \multicolumn{1}{c}{ Tipe Miskonsepsi } & $\begin{array}{c}\text { Persentase Rata-Rata } \\
\text { Siswa yang Mengalami } \\
\text { Miskonsepsi }\end{array}$ \\
\hline 1. & Konsep Suhu & $11.53 \%$ \\
2. & Konsep Kalor & $16.44 \%$ \\
3. & Konsep Pemuaian & $8.61 \%$ \\
4. & Konsep Perpindahan Kalor & $15.22 \%$ \\
\hline
\end{tabular}

Berdasarkan tabel yang tersaji di atas, terlihat bahwa persentase rata-rata siswa yang mengalami miskonsepsi terbanyak pada konsep kalor yaitu sebesar $16.44 \%$, sedangkan persentase rata-rata siswa yang mengalami miskonsepsi paling sedikit adalah pada konsep pemuaian yakni sebesar $8.61 \%$. Berdasarkan Tabel 3 di atas, dapat dibuat diagram seperti pada gambar berikut ini:

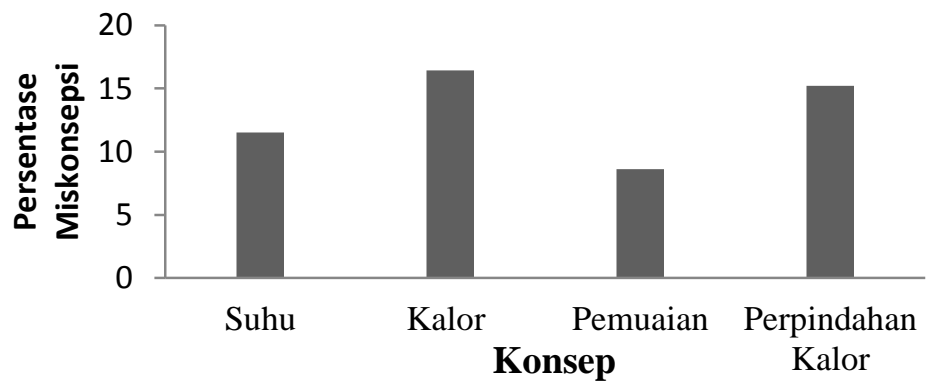

Gambar 3. Diagram Batang Persentase Rata-Rata Siswa Yang Mengalami Miskonsepsi Pada Tiap Tipe Soal Miskonsepsi 
Berdasarkan hasil analisis data penelitian yang telah dilakukan, terlihat bahwa miskonsepsi tentang konsep Suhu, Kalor, dan Perpindahan Kalor yang dimiliki oleh siswa kelas X SMKN 4 Mataram pada tahun 2015 dapat diidentifikasi dengan menggunakan instrumen tes identifikasi miskonsepsi pada penelitian ini.

\section{Konsep Suhu (Butir Soal Nomor 1, 2, 3, 4,dan 5)}

Pada konsep Suhu ini, rerata siswa yang mengalami miskonsepsi adalah $11.53 \%$, dimana siswa menganggap suhu benda sebanding dengan massa benda, miskonsepsi tentang kesetimbangan termal, jenis alat memasak tak mempengaruhi banyaknya kalor, dan ukuran benda sebanding dengan suhu.

2. Konsep Kalor (Butir Soal Nomor 6, 7, 8, 9, 10, 11, 12, dan 13)

Pada konsep Kalor ini, rerata siswa yang mengalami miskonsepsi adalah $16.44 \%$, dimana siswa menganggap kalor merupakan energi yang mengalir dari energi yang satu ke energi yang lain, berat benda sebanding dengan kalor, benda logam/mudah meleleh akan menerima kalor lebih banyak, miskonsepsi tentang pelepasan dan penyerapan kalor, benda yang dipanaskan suhunya selalu naik, massa benda berbanding terbalik dengan kalor, dan benda menyublim karena pengaruh suhu dingin serta posisi yang berdesakan.

3. Konsep Pemuaian (Butir Soal Nomor 14, 15, 16, 17, 18, dan 19)

Pada konsep Pemuaian ini, rerata siswa yang mengalami miskonsepsi adalah $8.61 \%$, dimana siswa menganggap diameter benda mengecil saat memuai, besar kecilnya pemuaian tergantung besar kecilnya api, besar kecilnya koefisien muai benda tergantung alat pemanas yang digunakan, partikel-partikel benda ukurannya semakin besar dan mendesak ke segala arah saat memuai, hanya akan terjadi pemuaian pada kayu yang dapat membuat kaca pecah, dan koefisien muai bagian dalam dan luar sebuah benda adalah berbeda.

\section{Konsep Perpindahan Kalor (Butir Soal Nomor 20, 21, 22, 23, 24 dan 25) \\ Pada konsep Perpindahan Kalor ini, rerata siswa yang mengalami miskonsepsi adalah $15.22 \%$, dimana}

siswa menganggap suhu dapat mengalir, miskonsepsi tentang fenomena konduksi, konveksi dan radiasi dalam kehidupan sehari-hari, dan tebal tipisnya benda mempengaruhi banyaknya kalor yang diserap.

Berdasarkan penjabaran di atas, terlihat bahwa hanya sebagian kecil dari siswa Kelas X SMKN 4 Mataram yang mengalami miskonsepsi, hal tersebut dikerenakan tes ini diberikan setelah materi pokok suhu, kalor, dan perpindahan kalor diajarkan di sekolah tersebut, terdapat beberapa siswa yang memiliki konsep awal yang sudah benar, guru menggunakan model pembelajaran kontekstual yang disertai dengan LKS saat melaksanakan proses pembelajaran di kelas, dan siswa memiliki antusiasme dalam belajar dan berupaya memiliki konsep yang benar.

Meskipun pembelajaran sudah dirancang sedemikian rupa, akan tetapi berdasarkan hasil tes yang diberikan ternyata jumlah siswa yang tidak paham konsep ternyata cukup banyak. Hal ini dapat disebabkan oleh rendahnya ketertarikan siswa akan mata pelajaran IPA khususnya pada materi Fisika dan siswa terbiasa hanya menghafalkan konsep sehingga konsep yang baru dipelajari tidak mampu dipahami. Selain itu, juga dapat disebabkan oleh rendahnya minat belajar siswa, siswa belum mampu menghubungkan konsep awal dengan konsep baru yang diberikan, serta kurangnya bakat dan kemampuan siswa dalam memahami materi.

\section{PenutuP}

Berdasarkan hasil penelitian dan pembahasan, maka dapat disimpulkan bahwa terdapat miskonsepsi pada siswa kelas X SMKN 4 Mataram Tahun Pelajaran 2014/2015 untuk materi pokok Suhu, Kalor, dan Perpindahan Kalor yang dinyatakan dalam rerata sebagai berikut:

1. Pada konsep suhu, persentase siswa yang tidak memahami konsep sebesar $30.45 \%$, siswa yang mengalami miskonsepsi sebesar $11.53 \%$, dan siswa yang memahami konsep sebesar $57.36 \%$.

2. Pada konsep kalor, persentase siswa yang tidak memahami konsep sebesar $41.74 \%$, siswa yang mengalami miskonsepsi sebesar $16.44 \%$, dan siswa yang memahami konsep sebesar $42.70 \%$. 
3. Pada konsep pemuaian, persentase siswa yang tidak memahami konsep sebesar $46.90 \%$, siswa yang mengalami miskonsepsi sebesar $8.61 \%$, dan siswa yang memahami konsep sebesar $44.54 \%$.

4. Pada konsep perpindahan kalor, persentase siswa yang tidak memahami konsep sebesar 37.29\%, siswa yang mengalami miskonsepsi sebesar $15.22 \%$, dan siswa yang memahami konsep sebesar $47.35 \%$.

Berdasarkan kesimpulan yang telah dijabarkan, maka saran yang dapat diberikan adalah sebagai berikut:

1. Guru sebaiknya perlu mengetahui prakonsepsi siswa sebelum memulai pembelajaran serta memberikan penekanan pada konsep yang benar untuk meminimalisasi terjadinya miskonsepsi pada siswa.

2. Penelitian ini dapat dikembangkan lebih lanjut dengan mengaitkan aspek-aspek yang belum diungkap seperti metode guru mengajar, buku ajar yang digunakan, dan prakonsepsi siswa agar lebih bermanfaat bagi dunia pendidikan khususnya pendidikan IPA (Fisika).

3. Penelitian ini dapat pula dikembangkan lebih lanjut dengan memberikan cara menanggulangi miskonsepsi yang terlanjur dimiliki oleh siswa.

\section{REFERENSI}

[1] Herayanti, Lovy dan Habibi. 2015. Model Pembelajaran Berbasis Masalah Berbantuan Simulasi Komputer Untuk Meningkatkan Keterampilan Berpikir Kritis Calon Guru Fisika. Jurnal Pendidikan Fisika dan Teknologi Volume 1 Nomor 1, 61-66.

[2] Sahidu, Chairunisyah. 2013. Penilaian Hasil Belajar. Mataram: Arga Puji Press.

[3] Putra, Sitiatava Rizema. 2013. Desain Belajar Mengajar Kreatif Berbasis Sains. Yogyakarta: Diva Press.

[4] Khasanah, Nunung. 2010. Penggunaan Pendekatan Konflik Kognitif untuk Remidiasi Miskonsepsi Pembelajaran Usaha dan Energi.
Tesis Program Studi Pendidikan Sains Universitas Sebelas Maret.

[5] Demircioglu, Gokhan, Alipayasa Ayas and Hulya Demircioglu. 2005. Conceptual Change Achieved Through a New Teaching Program on Acid and Bases. Journal of Chemistry Educational Research and Practice Volume 6 Number 1, 3651.

[6] Berg, Euwe Van Den. 1991. Miskonsepsi Fisika dan Remediasi. Salatiga: Universitas Kristen Satya Wacana.

[7] Barke, Hans-Dieter, Al Hazari and Sileshi Yitbarek. 2009. Misconceptions in Chemistry Addressing Perceptions in Chemical Education. Germany: Springer.

[8] Suparno, Paul. 2005. Miskonsepsi dan Perubahan Konsep dalam Pendidikan Fisika. Jakarta: PT Grasindo.

[9] Dahar, Ratna Wilis. 1988. Teori-Teori Belajar. Bandung: Erlangga.

[10] Mahmudah, Roisatul. (2013). Identifikasi Miskonsepsi Peserta Didik Konsep Suhu dan Kalor dengan Menggunakan Peta Konsep dan Wawancara. Skripsi Program Studi Pendidikan Fisika Universitas Islam Negeri Sunan Kalijaga Yogyakarta: tidak diterbitkan.

[11] Musfiqon, H. M. (2012). Panduan Lengkap Metodologi Penelitian Pendidikan. Jakarta: Prestasi Pustakarya.

[12] Sugiyono. (2014). Metode Penelitian Pendidikan Pendekatan Kuantitatif, Kualitatif, dan $R \& D$. Bandung: Alfabeta.

[13] Kurniawati, Isdiana. (2013). Profil Miskonsepsi Siswa Kelas X SMA Negeri 7 Surakarta Konsep Listrik Dinamis. Skripsi Program Studi Pendidikan Fisika Universitas Sebelas Maret: tidak diterbitkan. 